Int. J. Dev. Biol. 49: 579-584 (2005)

doi: $10.1387 /$ ijdb.051983ss

\title{
Epidermal differentiation: trichomes in Arabidopsis as a model system
}

\author{
SWEN SCHELLMANN and MARTIN HÜLSKAMP* \\ University of Köln, Botanical Institute III, Köln, Germany
}

\begin{abstract}
Arabidopsis trichomes are an excellent model system to study all aspects of cell differentiation including cell fate determination, cell cycle regulation, cell polarity and cell expansion. Genetic analysis had initially identified mutants affecting trichome development at different developmental stages. During recent years, molecular analysis of the corresponding genes has revealed a first glimpse of the underlying molecular mechanisms. This paper summarizes some of the recent insights regarding the mechanisms of trichome development.
\end{abstract}

KEY WORDS: trichome, Arabidopsis, cytoskeleton, patterning, differentiation

The analysis of the development of single cells has been very successful to unravel the interplay of specific developmental regulation events and of more general cellular functions. In the model plant Arabidopsis in particular root hairs, pollen tubes, stomata cells and leaf trichomes have been studied in great detail. Although this review focuses on trichome development references to other cell types are included due to the fact that some mutations also affect the development of other cell types in a characteristic manner.

\section{Development of Arabidopsis trichomes}

Trichomes are thought to be important to protect the plant against herbivores, loss of water through transpiration and UV irradiation (Johnson, 1975; Mauricio and Rausher, 1997). In Arabidopsis trichomes are found on most aerial parts of the plant including rosette leaves, stem and cauline leaves but not on the hypocotyl and the cotyledons. Morphology and density differs dramatically on different organs. While trichomes on rosette leaves have 3-4 branches, cauline trichomes show reduced branching and stem trichomes are unbranched. Trichome density on the abaxial side of leaves increases significantly with the plant changing from vegetative to reproductive growth and serves as a convenient marker to search for mutants affecting the transition (Telfer et al., 1997).

The analysis of trichome development has mainly focused on trichomes growing on rosette leaves (Marks, 1997; Hulskamp etal., 1999; Larkin et al., 2003). Here they develop at the base of young leaves in a field of rapidly dividing protodermal cells, some of which are chosen to differentiate into trichomes. Trichome initials are well spaced and almost never occur next to each other. As clustered trichomes would be expected in case of a random distribution it is evident that a mechanism regulating the spacing must exist (Larkin et al., 1996). Incipient trichome cells switch from mitotic divisions to replication cycles without cell divisions (endoreduplication) (Hulskamp et al., 1994). The trichome cell undergoes four endoreduplication cycles resulting in a DNA content of $32 \mathrm{C}$. The trichome enlarges, expands away from the surface and initiates two or more branching events. The orientation of the branches is co-aligned with respect to the leaf basal-apical axis and also the angles between the branches are very regular (Folkers et al., 1997).

\section{Mutational analysis of trichome development}

A large number of mutants were isolated in different labs that show defects in trichome development (Marks, 1997; Hulskamp et al., 1999; Larkin et al., 2003). Although the initial screens have identified the major classes of genes required for the key steps of trichome development the number of genes identified to be important for trichome development is steadily growing. This is not only due to higher saturation reached by more intensive screens but also to the application of more refined criteria for mutant evaluations. Initially the mutants were categorized according to the developmental steps that were affected (Hulskamp et al., 1994). A first class of mutants affects trichome initiation such that fewer or more trichomes are formed. A second class of mutants caused aberrations in the regulation of endoreduplication including alterations in the number of endoreduplication cycles or the initial switch

Abbreviations used in this paper: F-Actin, filamentous actin; WAVE, WiscottAldrich syndrome protein family Verprolin-homologous protein.

*Address correspondence to: Dr. Martin Hülskamp. University of Köln, Botanical Institute III, Gyrhofstr. 15, 50931 Köln, Germany. Fax: +49-221-470-5062.
e-mail: martin.huelskamp@uni-koeln.de 
from mitosis to endoreduplication. A third class of mutants resulted in an increased or decreased number of branches. A fourth class of mutants showed randomized growth suggesting that they are involved in the directionality of expansion growth. A fifth class of mutants appears to generally affect the maturation of trichomes. This class of mutants will not be considered here as no deeper analysis on these has been reported to date. The molecular and genetic analysis has revealed that each class of genes is very heterogeneous with respect to the underlying cell biological and biochemical mechanisms.

\section{Selecting trichome fate in the epidermis}

The regular distribution of trichomes on the leaf epidermis is not obviously linked to any underlying pattern of other cell types or structures in the leaf and hence its establishment requires a mechanism that creates a pattern de novo. Clonal analysis experiments rule out the possibility that a stereotype cell division pattern creates the distribution pattern (Larkin etal., 1996; Schnittger etal., 1999). Therefore the pattern has to be created by intercellular communication. The current models that are based on a theoretical model formulated by Hans Meinhardt (Meinhardt, 1982; Meinhardt, 1994) assume that initially all cells express trichome promoting factors and that these activate their own repressors that can move between cells thereby initiating a competition between the cells (Larkin et al., 2003; Pesch and Hulskamp, 2004). Theoretical considerations require that the trichome promoting factors can self-enhance to enable the rapid amplification of small differences arising from small and random fluctuations.

Genetically, several genes were identified that classify as trichome promoting or trichome repressing factors and generally,

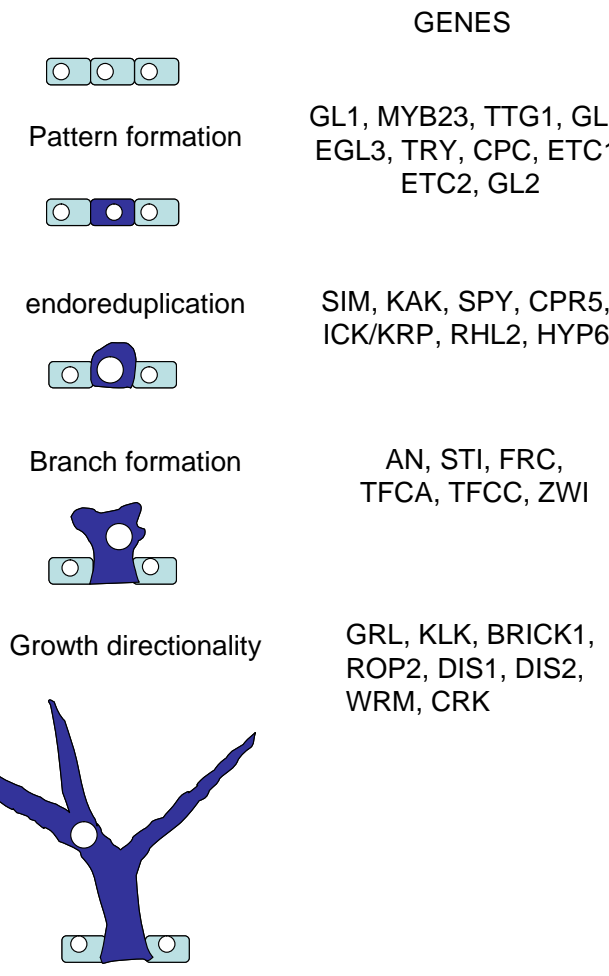

Fig. 1. Trichome development and mutants affecting each developmental stage. their genetic interactions are consistent with the above mentioned model (Schnittger et al., 1998; Szymanski and Marks, 1998; Schnittger et al., 1999).

Mutations in three genes result in a reduced number of trichomes, GLABRA3 (GL3), or the complete absence of trichomes, GLABRA1 (GL1), TRANSPARENT TESTA GLABRA1 (TTG1) and are therefore considered positive regulators of trichome development (Koornneef, 1981; Koornneef et al., 1982; Hulskamp etal., 1994). The function of $G L 3$ is redundant with its close homolog ENHANCER OF GLABRA3 (EGL3). If both genes are mutated, the plant is glabrous (Zhang et al., 2003). GL 1, GL3 and EGL3 are likely to act as transcriptional regulators as $G L 1$ encodes a MYBrelated transcription factor and $G L 3$ and $E G L 3$ encode helix-loophelix factors (Oppenheimer et al., 1991; Payne et al., 2000; Zhang etal., 2003). TTG1 encodes a WD40 domain protein (Walker etal., 1999) and was shown to interact with GL3 suggesting that it acts as a transcriptional coregulator (Payne et al., 2000).

TRIPTYCHON ( TRY) was the first identified negative regulator of trichome development. The try mutants show clusters of trichomes suggesting that the lateral suppression of trichome fate is affected. TRY encodes a small single R3-MYB-repeat protein that has no obvious activation domain (Schellmann et al., 2002). The function of $T R Y$ is controlled redundantly by at least four genes that are close homologs: The root hair patterning gene CAPRICE (CPC) turned out to function also during trichome patterning such that $c p c$ mutants have more trichomes than wild type. The try $c p c$ double mutant showed extremely enlarged clusters containing up to 40 trichomes. Recently two more TRY/ CPC-like genes, ENHANCER OF TRY AND CPC 1 (ETC1) and ETC2 have been shown to act redundantly with TRY and CPC. The try cpc etc2 triple mutant has additional trichomes at the leaf borders (Kirik et al., 2004a) and the try cpc etc1 triple mutant has leaves that are almost completely covered with trichomes (Kirik et al., 2004b).

Yeast two hybrid interaction assays have revealed that the patterning proteins interact with each other in a characteristic manner. GL3 and EGL3 interact with TTG1 and GL1 but GL1 and TTG1 do not directly interact (Payne et al., 2000; Zhang et al., 2003). In addition TRY was shown to interact with GL3 and the recent finding by Esch and coworkers that TRY and GL1 compete for binding to GL3 suggests a model according to which in trichomes an active complex consisting of GL1, GL3 and TTG1 is operating and in non-trichome cells the complex consisting of TRY, GL3 and TTG1 is inactive (Esch et al., 2003). The cellular interactions required for the cells to interact are thought to be mediated by the negative regulators moving between the cells. The ability to move between cells is so far only documented for CPC. When CPC:GFP fusion protein is expressed under the $C P C$ promoter that confers expression only in non-hair cell-files (atrichoblasts), the fluorescence of the fusion protein was not only found in the atrichoblasts but also in the trichoblasts demonstrating the movement ability of CPC (Wada et al., 2002).

The combined action of the patterning genes results in the trichome specific expression of GLABRA2 (GL2). GL2 encodes a homeobox transcription factor and is thought to be the first target gene of the patterning machinery and responsible for mediating their input into trichome differentiation (Rerie et al., 1994; Cristina et al., 1996; Szymanski et al., 1998). A role of GL2 in cell differentiation is indicated by the finding that $G L 2$ regulates the 
signal transduction factor phospholipase $D \zeta 1$ during root hair development and that phospholipase $D \zeta 1$ in turn controls cell differentiation in the root epidermis (Ohashi etal., 2003). In addition GL2 seems also to be involved in earlier patterning events as the introduction of additional copies of GL2 in wild type plants results in an altered trichome pattern (Ohashi et al., 2002).

\section{The first step into cell differentiation: the switch from mitosis to endoreduplication}

The first visible morphological change of a trichome initial is the increased nucleus resulting from the first endoreduplication cycle. Two types of experiments allow a first glimpse of how this switch from mitosis to endoreduplication is controlled. Mutations in the SIAMESE (SIM) gene lead to multicellular trichomes (Walker et al., 2000); the molecular nature of the SIM gene has not been reported yet. A second approach towards an understanding of how the switch from mitosis to endoreduplication is regulated is misexpression studies. Trichome-specific expression of known cell cycle genes allowed to circumvent gametophytic or embryonic lethality and to analyze the affect of their overexpression on trichome development. Overexpression of a specific B-type cyclin, which normally triggers the transition from $\mathrm{G} 2$ to mitosis caused a similar phenotype as sim mutants (Schnittger et al., 2002b). GL2:CYCB1,2 plants have multicellular trichomes with a total amount of DNA similar to wild type. Also D-type cyclin overexpression led to multicellular trichomes. This was surprising as D-type cyclins normally regulate the transition from $\mathrm{G} 1$ to $S$ phase, though consistent with this latter function the total amount of DNA per trichome was also increased (Schnittger et al., 2002a).

\section{Stopping growth: regulation of the number of endoreduplication cycles}

Several trichome mutants show either reduced or increased ploidy levels (Hulskamp et al., 1994; Jacobsen et al., 1996; Perazza et al., 1999; Kirik et al., 2001; Sugimoto-Shirasu et al., 2002). The genetic and molecular analysis revealed no coherent regulation scheme. The ploidy level is rather controlled independently by various pathways. The first pathway controlling the ploidy level is utilizing the above described patterning genes. Mutations in $G L 3$ and $T R Y$ result in reduced and increased ploidy levels respectively suggesting that the patterning genes have a second role in the regulation of the progression of endoreduplication cycles (Hulskamp et al., 1994; Esch et al., 2003). A second pathway is likely to be controlled by the regulation of protein degradation. The KAKTUS (KAK) gene is important to repress endoreduplication after the fourth endoreduplication cycle; the kak mutants have a DNA content of $64 \mathrm{C}$. The recent cloning of the $K A K$ gene revealed that the gene encodes a putative E3 ligase suggesting that $K A K$ regulates the ploidy level by ubiquitinating proteins normally promoting the progression of endoreduplication cycles (Downes et al., 2003; El Refy et al., 2004). Third, the plant hormone gibberellin seems to act as a positive regulator of the ploidy level in trichomes. The spindly (spy) mutant, which behaves as a constitutive gibberellin response mutant, has trichomes with twice the ploidy level as wild type (Jacobsen and Olszewski, 1993). Fourth, one pathway seems to be linked to the cell-death regulation. One line of evidence for this is the finding that the constitutive pathogen

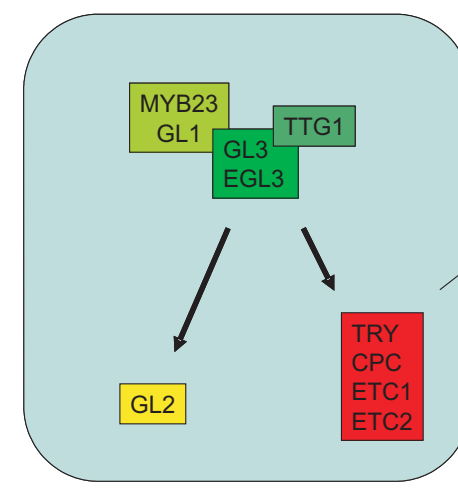

trichome initial

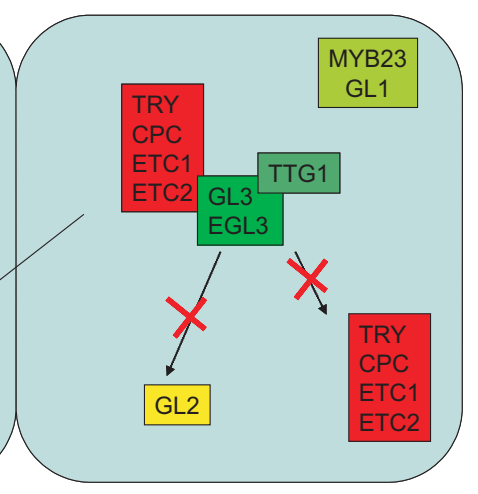

epidermal cell
Fig. 2. Patterning Model. Activators of trichome fate are depicted in green shades, inhibitors are in red. Arrows indicate transcriptional activation. In trichome cells the inhibitors are activated by the activating complex and move into neighboring cells, where they block the activity of the activating complex thereby inhibiting trichome fate.

response5 (cpr5) mutant exhibits trichomes with reduced ploidy (Kirik et al., 2001). The second line of evidence is the observation that overexpression of INHIBITOR/INTERACTOR OF CYCLINDEPENDENT KINASES/KIP-RELATED PROTEINS (ICK/KRP) causes reduced ploidy in trichomes and eventually cell death (Schnittger et al., 2003). Finally, also DNA-topoisomerases involved in the ATP-dependent separation of entangled DNA are required for the progression of endoreduplication cycles. ROOT HAIRLESS2 (RHL2) and HYPOCOTYL6 (HYP6) encode components of the DNA TOPOSOMERASE VI complex and both promote the progression of endoreduplication cycles (Hartung et al., 2002; Sugimoto-Shirasu et al., 2002). One explanation is that in the absence of the isomerase activities a physical block inhibits further replication. Alternatively, the isomerases may be regulators that activate specific cell cycle checkpoints.

\section{Regulation of branch number}

A large number of branching mutants have been identified in which the number of branches is either increased or reduced (Folkers et al., 1997; Luo and Oppenheimer, 1999). Generally, mutants with altered ploidy levels are also affected in branch number such that mutants with a reduced DNA content have fewer branches and mutants with increased ploidy levels have more branches (Hulskamp et al., 1994; Folkers et al., 1997). This correlation between ploidy level and branch number indicates that either the size or the growth time is relevant for the initiation of branches. The analysis of drug-treated trichomes and mutant analysis both point to the microtubules as an important regulator of branch initiation. Microtubule drugs not only result in isotropic growth but also inhibit the formation of branches. Conversely the stabilization of microtubules can rescue the unbranched mutant stiche/ (sti) (Mathur and Chua, 2000). Several mutations in factors regulating the microtubules were characterized that have little effect on general growth and more specific branching phenotypes enabling to analyze the role of microtubules more specifically. Mutations in the TUBULIN FOLDING COFACTOR (TFC) $C$ and TFCA cause an underbranched trichome phenotype (Kirik et al., 2002a; Kirik etal., 2002b). These mutants are expected to interfere 
with the making of assembly competent $\alpha / \beta$ tubulin dimers and are likely to be compromised in the assembly of new microtubules. Thus, the formation of new microtubules is likely to be important for the formation of new branches. Also mutations in factors required for cutting of already existing microtubules, the katanins result in reduced trichome branching. Taken together it is therefore likely that local destruction and new synthesis of microtubules is important to initiate branching. The spatial organization of microtubules is another level of regulation. Mutations in FASS/TONNEAU2 and $S P I K E$ lead to defects in microtubule organization (Traas et al., 1995; Qiu et al., 2002). FASS/TONNEAU2 encodes a phosphatase-2A subunit and regulates the microtubules by phosphorylation of other proteins (Camilleri et al., 2002). The SPIKE gene encodes a protein related to CDM-family (Caenorhabditis elegans CED-5; Homosapiens DOCK180) adaptor proteins, which trigger further downstream events through small RHO-like GTPases (Qiu et al., 2002). The mechanisms by which FASS/TONNEAU2 and $S P I K E$ regulate the microtubule cytoskeleton and branching of trichomes in Arabidopsis are still elusive. Finally, also transport along the microtubules may be a specific aspect of branch initiation as mutations in the kinesin motor molecule ZWICHEL (ZWI) lead to reduced branching (Oppenheimer et al., 1997). ZWICHEL was shown to bind to microtubules in a calmodulin-dependent manner and its activity is controlled by the KIC protein, which binds to $Z W /$ in a calmodulin-dependent manner (Deavours et al., 1998; Reddy et al., 2004). This implies that Ca2+ may also be involved in the regulation of branch formation. The ANGUSTIFOLIA $(A N)$ gene appears to be involved in creating a high concentration of microtubules at the tip of the trichome cell. How this is achieved is still mysterious. On the one hand $A N$ interacts with $Z W /$ in yeast two hybrid essays suggesting a direct involvement. On the other hand $A N$ encodes a protein with sequence similarity to CtBP/BARS which would suggest a rather indirect regulation of microtubules by AN (Folkers et al., 2002; Kim et al., 2002). CtBP (C-terminal binding proteins) are transcriptional co-factors with a functional

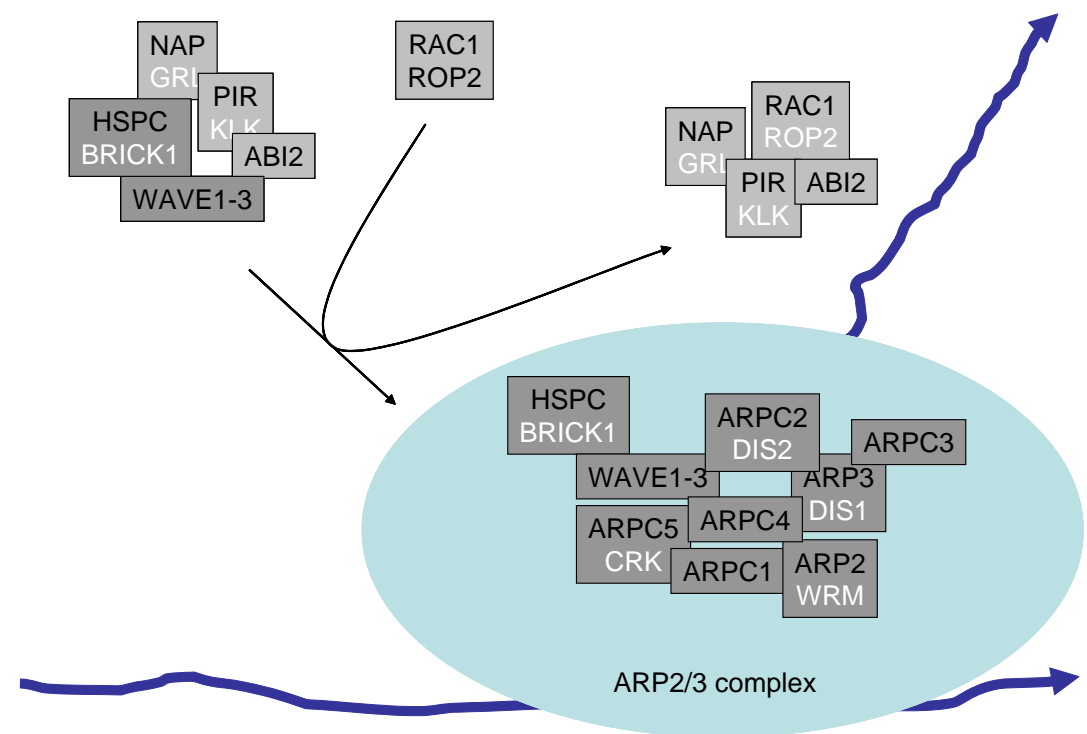

Fig. 3. Regulation of actin by the Arp2/3 complex. (Explanation in the text). The growing actin strands are depicted in blue, arrowheads indicate the growth direction. Names of plant proteins homologous to the animal proteins are mentioned in white. overlap to factors called BARS (Brefeldin A Ribosylated Substrates) (Matteis et al., 1994; Nibu et al., 1998).

The only trichome branching gene with undisturbed microtubule organization is the STICHEL (STI) gene. STICHEL appears to regulate branching in a dosage dependent manner as the strength of the phenotype is correlated with the activity of the STI-activity. The molecular function of STICHEL is unknown. The STI gene encodes a protein with sequence similarity to the DNA-polymerase-III subunits, but no replication phenotype is observed in the sti mutants (Ilgenfritz et al., 2003).

\section{Growing straight: trichome expansion is regulated by actin}

A group of eight genes, that are collectively referred to as "distorted" mutants share a common trichome phenotype: trichomes develop fairly normal until the branches have been initiated and with the onset of cell expansion branches grow in a randomized manner such that they may twist and bulge or do not grow at all (Hulskamp et al., 1994; Schwab et al., 2003). In addition to the trichome phenotype for some of the mutants also other cell types show morphological defects. These include aberrant root hair growth, the formation of lobes in the pavement cells and the bending of hypocotyl cells out of the epidermal cell layer (Le et al., 2003; Mathur et al., 2003a; Mathur et al., 2003b; El-Assal et al., 2004b; Saedler et al., 2004). The two observations that trichomes treated with drugs interfering with actin function and that most of the "distorted" mutants show an aberrant actin organization strongly suggested that the "distorted" genes regulate cell expansion through the actin cytoskeleton (Mathur etal., 1999; Szymanski etal., 1999). Consistent with this four of the "distorted" genes encode components of the ARP2/3 complex (Li et al., 2003; Mathur et al., 2003a; Mathur et al., 2003b; El-Assal et al., 2004b Saedler et al., 2004). The ARP2/3 complex is known to promote actin formation by initiating F-actin polymerization of new actin filaments on already existing actin (Mullins et al., 1998; Svitkina and Borisy, 1999). The cell biological analysis revealed that actin function is not generally impaired in arp2/3 mutants as peroxisome and Golgi movement along the actin cytoskeleton is still observed. Locally, striking differences were observed in that the velocity was higher in growth regions then in non-growth regions (Mathur et al., 2003a; Mathur et al., 2003b). Another cellular phenotype seen in arp2/3 mutant trichomes is that the fusion of the central vacuole did not occur and as a consequence multiple smaller vacuoles are formed (Mathur et al., 2003a).

The central question of how ARP2/3 activity is spatially controlled is largely unresolved, though evidence is accumulating that suggests that a pathway related to the "WAVE" pathway in animals may exist. The WAVE pathway begins with the perception of signals that regulate the activity of small $\mathrm{RHO}$ and RAC-like GTPases. The activated forms bind to a large complex consisting of the two ARP2/3 activating proteins HSPC300 and WAVE and the three repressors PIR121, NAP125 and Abi2. Binding of the small GTPase to the complex releases the three inhibitors and results in the activation of HSPC300 
and WAVE. In plants small GTPases related to RHO and RAC/ CDC42 called ROPs are known and were shown to be involved in the control of actin organization (Yang, 2002; Mathur and Hulskamp, 2002; Smith, 2003). Also two of the immediate targets of ROPs, NAP125, PIR121, were identified (Basu et al., 2004; Brembu et al., 2004; Deeks et al., 2004; El-Assal et al., 2004a; Li et al., 2004; Zimmermann et al., 2004). The corresponding mutants show a similar phenotypic range as the arp2/3 mutants indicating that they are acting in the same pathway. In addition the HSPC300 homolog (BRICK1) was found in maize (Frank and Smith, 2002). The existence of a functional WAVE homolog is still not demonstrated though putative homologs were described based on sequence similarity comparisons (Brembu et al., 2004).

\section{References}

BASU, D., EL-ASSAL SEL, D., LE, J., MALLERY, E. L. and SZYMANSKI, D. B. (2004). Interchangeable functions of Arabidopsis PIROGI and the human WAVE complex subunit SRA1 during leaf epidermal development. Development 131: 4345-55.

BREMBU, T., WINGE, P., SEEM, M. and BONES, A. M. (2004). NAPP and PIRP encode subunits of a putative wave regulatory protein complex involved in plant cell morphogenesis. Plant Cell 16, 2335-49.

CAMILLERI, C., AZIMZADEH, J., PASTUGLIA, M., BELLINI, C., GRANDJEAN, O. and BOUCHEZ, D. (2002). The Arabidopsis TONNEAU2 Gene Encodes a Putative Novel Protein Phosphatase 2A Regulatory Subunit Essential for the Control of the Cortical Cytoskeleton. Plant Cell 14, 833-45.

CRISTINA, M. D., SESSA, G., DOLAN, L., LINSTEAD, P., RUBERTI, S. and MORELLI, G. (1996). The Arabidopsis Athb-10 (GLABRA2) is an HD-Zip protein required for regulation of root hair development. Plant Journal 10, 393-402.

DEAVOURS, B. E., REDDY, A. S. and WALKER, R. A. (1998). Ca2+/calmodulin regulation of the Arabidopsis kinesin-like calmodulin-binding protein. Cell Motility and the Cytoskeleton 40, 408-416.

DEEKS, M. J., KALORITI, D., DAVIES, B., MALHO, R. and HUSSEY, P. J. (2004). Arabidopsis NAP1 is essential for Arp2/3-dependent trichome morphogenesis. Curr Biol.

DOWNES, B. P., STUPAR, R. M., GINGERICH, D. J. and VIERSTRA, R. D. (2003). The HECT ubiquitin-protein ligase (UPL) family in Arabidopsis: UPL3 has a specific role in trichome development. Plant J. 35, 729-42.

EL REFY, A., PERAZZA, D., ZEKRAOUI, L., VALAY, J. G., BECHTOLD, N., BROWN, S., HULSKAMP, M., HERZOG, M. and BONNEVILLE, J. M. (2004). The Arabidopsis KAKTUS gene encodes a HECT protein and controls the number of endoreduplication cycles. Mol. Genet. Genomics 270, 403-14.

EL-ASSAL, S., LE, J., BASU, D., MALLERY, E. L. and SZYMANSKI, D. B. (2004a). Arabidopsis GNARLED encodes a NAP125 homolog that positively regulates ARP2/3. Current Biology.

EL-ASSAL, S., LE, J., BASU, D., MALLERY, E. L. and SZYMANSKI, D. B. (2004b). DISTORTED2 encodes an ARPC2 subunit of the putative Arabidopsis ARP2/3 complex. Plant J 38, 526-38.

ESCH, J. J., CHEN, M., SANDERS, M., HILLESTAD, M., NDKIUM, S., IDELKOPE, B., NEIZER, J. and MARKS, M. D. (2003). A contradictory GLABRA3 allele helps define gene interactions controlling trichome development in Arabidopsis. Development 130, 5885-5894.

FOLKERS, U., BERGER, J. and HULSKAMP, M. (1997). Cell morphogenesis of trichomes in Arabidopsis: differential control of primary and secondary branching by branch initiation regulators and cell growth. Development 124, 3779-86.

FOLKERS, U., KIRIK, V., SCHOBINGER, U., FALK, S., KRISHNAKUMAR, S., POLLOCK, M. A., OPPENHEIMER, D. G., DAY, I., REDDY, A. R., JURGENS, G. and HULSKAMP, M. (2002). The cell morphogenesis gene ANGUSTIFOLIA encodes a CtBP/BARS-like protein and is involved in the control of the microtubule cytoskeleton. EMBO J. 21, 1280-1288.

FRANK, M. J. and SMITH, L. G. (2002). A small, novel protein highly conserved in plants and animals promotes the polarized growth and division of maize leaf epidermal cells. Curr Biol 12, 849-53.

HARTUNG, F., ANGELIS, K. J., MEISTER, A., SCHUBERT, I., MELZER, M. and
PUCHTA, H. (2002). An archaebacterial topoisomerase homolog not present in other eukaryotes is indispensable for cell proliferation of plants. Curr Bio/ 12, 178791.

HULSKAMP, M., MISERA, S. and JÜRGENS, G. (1994). Genetic dissection of trichome cell development in Arabidopsis. Cell 76, 555-566.

HULSKAMP, M., SCHNITTGER, A. and FOLKERS, U. (1999). Pattern formation and cell differentiation: Trichomes in Arabidopsis as a genetic model system. Int. Rev. Cytol. 186, 147-178.

ILGENFRITZ, H., BOUYER, D., SCHNITTGER, A., MATHUR, J., KIRIK, V., SCHWAB, B., CHUA, N.-H., JÜRGENS, G. and HULSKAMP, M. (2003). The Arabidopsis STICHEL Gene is a Regulator of Trichome Branch Number and Encodes a Novel Protein. Plant Physiology. Plant Physiol. 131, 643-655.

JACOBSEN, S. E., BINKOWSKI, K. A. and OLSZEWSKI, N. E. (1996). SPINDLY, a tetratricopeptide repeat protein involved in gibberellin signal transduction in Arabidopsis. Proc. Natt. Acad. Sci. USA 93, 9292-9296.

JACOBSEN, S. E. and OLSZEWSKI, N. E. (1993). Mutations in the SPINDLY locus of Arabidopsis alter gibberellin signal transduction. Plant Cell 5, 887-896.

JOHNSON, H. B. (1975). Plant pubescence: an ecological perspective. Bot. Rev. 41, 233-258.

KIM, G. T., SHODA, K., TSUGE, T., CHO, K.-H., UCHIMIYA, H., YOKOYAMA, R., NISHITANI, K. and TSUKAYA, H. (2002). The ANGUSTIFOLIAgene of Arabidopsis, a plant CtBP gene, regulates leaf-cell expansion, the arrangement of cortical microtubules in leaf cells and expression of a gene involved in cell-wall formation. EMBO J. 26, 1267-1279.

KIRIK, V., BOUYER, D., SCHOBINGER, U., BECHTOLD, N., HERZOG, M., BONNEVILLE, J. M. and HULSKAMP, M. (2001). CPR5 is involved in cell proliferation and cell death control and encodes a novel transmembrane protein. Curr. Biol. 11, 1891-5.

KIRIK, V., GRINI, P. E., MATHUR, J., KLINKHAMMER, I., ADLER, K., BECHTOLD, N., HERZOG, M., BONNEVILLE, J. M. and HULSKAMP, M. (2002a). The Arabidopsis TUBULIN-FOLDING COFACTOR A gene is involved in the control of the alpha/ beta-tubulin monomer balance. Plant Cell 14, 2265-76.

KIRIK, V., MATHUR, J., GRINI, P. E., KLINKHAMMER, I., ADLER, K., BECHTOLD, N., HERZOG, M., BONNEVILLE, J. M. and HULSKAMP, M. (2002b). Functional analysis of the tubulin-folding cofactor $\mathrm{C}$ in Arabidopsis thaliana. Curr. Biol. 12, 1519-23.

KIRIK, V., SIMON, M., HULSKAMP, M. and SCHIEFELBEIN, J. (2004a). The ENHANCER OF TRY AND CPC1 (ETC1) gene acts redundantly with TRIPTYCHON and CAPRICE in trichome and root hair cell patterning in Arabidopsis. Dev. Biol. 268, 506-513.

KIRIK, V., SIMON, M., WESTER, K., SCHIEFELBEIN, J. and HÜLSKAMP, M. (2004b). ENHANCER of TRY and CPC 2 (ETC2) reveals redundancy in the region-specific control of trichome development of" Arabidopsis. Plant Molec. Biol. (in press).

KOORNNEEF, M. (1981). The complex syndrome of ttg mutants. Arabidopsis Information Service 18, 45-51.

KOORNNEEF, M., DELLAERT, L. W. M. and VEEN, J. H. V. d. (1982). EMS- and radiation-induced mutation frequencies at individual loci in Arabidopsis thaliana. Mutat. Res. 93, 109-123.

LARKIN, J. C., BROWN, M. L. and SCHIEFELBEIN, J. (2003). How do cells know what they want to be when they grow up? Lessons from epidermal patterning in Arabidopsis. Annu. Rev. Plant Biol. 54, 403-30.

LARKIN, J. C., YOUNG, n., PRIGGE, M. and MARKS, M. D. (1996). The control of trichome spacing and number in Arabidopsis. Development 122, 997-1005.

LE, J., EL-ASSAL SEL, D., BASU, D., SAAD, M. E. and SZYMANSKI, D. B. (2003). Requirements for Arabidopsis ATARP2 and ATARP3 during epidermal development. Curr. Biol. 13, 1341-7.

LI, S., BLANCHOIN, L., YANG, Z. and LORD, E. M. (2003). The putative Arabidopsis arp2/3 complex controls leaf cell morphogenesis. Plant Physiology 132, 2034-44.

LI, Y., SOREFAN, K., HEMMANN, G. and BEVAN, M. W. (2004). Arabidopsis NAP and PIR Regulate Actin-Based Cell Morphogenesis and Multiple Developmental Processes. Plant Physiol.

LUO, D. and OPPENHEIMER, D. G. (1999). Genetic control of trichome branch number in Arabidopsis: the roles of the FURCA loci. Development 126, 5547-5557.

MARKS, M. D. (1997). Molecular genetic analysis of trichome development in Arabidopsis. Ann. Rev. Plant Physiol. Plant Molec. Biol. 48, 137-163.

MATHUR, J. and CHUA, N.-H. (2000). Microtubule stabilization leads to growth 
reorientation in Arabidopsis thaliana trichomes. Plant Cell 12, 465-477.

MATHUR, J. and HULSKAMP, M. (2002). Signal Transduction: Rho-like Proteins in Plants. Curr. Biol. 12, R526-R528.

Mathur, J., Mathur, N., Kernebeck, B. and Hulskamp, M. (2003a). Mutations in actinrelated proteins 2 and 3 affect cell shape development in Arabidopsis. Plant Cel/15, 1632-45.

MATHUR, J., MATHUR, N., KIRIK, V., KERNEBECK, B., SRINIVAS, B. P. and HULSKAMP, M. (2003b). Arabidopsis CROOKED encodes for the smallest subunit of the ARP2/3 complex and controls cell shape by region specific fine F-actin formation. Development 130, 3137-46.

MATHUR, J., SPIELHOFER, P., KOST, B. and CHUA, N.-H. (1999). The actin cytoskeleton is required to elaborate and maintain spatial patterning during trichome cell morphogenesis in Arabidopsis thaliana. Development 126, 5559-5568.

MATTEIS, M. D., GIROLAMO, M. D., COLANZI, A., PALLAS, M., TULLIO, G. D., MCDONALD, L., MOSS, J., SANTINI, G., BANNYKH, S., CORDA, D. and LUINI, A. (1994). Stimulation of endogenous ADP-rebosylation by brefeldin A. Proc. Natt. Acad. Sci. USA 91, 1114-1118.

MAURICIO, R. and RAUSHER, M. D. (1997). Experimental manipulation of putative selective agents provides evidence for the role of natural enemies in the evolution of plant defense. Evolution 51, 1435-1444.

MEINHARDT, H. (1982). «Models of biological pattern formation.» Academic Press, London, New York, Paris.

MEINHARDT, H. (1994). Biological pattern formation: New observations provide support for theoretical predictions. BioEssay 16, 627-632.

MULLINS, R. D., HEUSER, J. A. and POLLARD, T. D. (1998). The interaction of Arp2/ 3 complex with actin: nucleation, high affinity pointed end capping and formation of branching networks of filaments. Proc. Natt. Acad. Sci. USA 95, 6181-6186.

NIBU, Y., ZHANG, H. and LEVINE, M. (1998). Interaction of a short-range repressors with Drosophila CtBP in the embryo. Science 280, 101-104.

OHASHI, Y., OKA, A., RODRIGUES-POUSADA, R., POSSENTI, M., RUBERTI, I., MORELLI, G. and AOYAMA, T. (2003). Modulation of Phospholipid Signaling by GLABRA2 in Root-Hair Pattern Formation. Science 300, 1427-1430.

OHASHI, Y., RUBERTI, I., MORELLI, G. and AOYAMA, T. (2002). Entopically additive expression of GLABRA2 alters the frequency and spacing of trichome initiation. Plant J. 21, 5036-5046.

OPPENHEIMER, D. G., HERMAN, P. L., SIVAKUMARAN, S., ESCH, J. and MARKS, M. D. (1991). A myb gene required for leaf trichome differentiation in Arabiopsis is expressed in stipules. Cel/ 67, 483-493.

OPPENHEIMER, D. G., POLLOCK, M. A., VACIK, J., SZYMANSKI, D. B., ERICSON, B., FELDMANN, K. and MARKS, M. D. (1997). Essential role of a kinesin-like protein in Arabidopsis trichome morphogenesis. Proc. Natl. Acad. Sci. USA94, 6261-6266.

PAYNE, C. T., ZHANG, F. and LLOYD, A. M. (2000). GL3 encodes a bHLH protein that regulates trichome development in Arabidopsis through interaction with GL1 and TTG1. Genetics 156, 1349-1362.

PERAZZA, D., HERZOG, M., HULSKAMP, M., BROWN, S., DORNE, A. and BONNEVILLE, J. (1999). Trichome cell growth in Arabidopsis thaliana can be depressed by mutations in at least five genes. Genetics 152, 461-76.

PESCH, M. and HULSKAMP, M. (2004). Creating a two-dimensional pattern de novo during Arabidopsis trichome and root hair initiation. Curr. Opin. Genet. Dev. 14, 422-427.

QIU, J. L., JILK, R., MARKS, M. D. and SZYMANSKI, D. B. (2002). The Arabidopsis SPIKE1 gene is required for normal cell shape control and tissue development. Plant Cell 14, 101-118.

REDDY, V. S., DAY, I., THOMAS, T. and REDDY, A. S. N. (2004). KIC, a novel CA2+ binding protein with one EF-hand motif, interacts with a microtubule motor protein and regulates trichome morphogenesis. Plant Cel/ 16, 185-200.

RERIE, W. G., FELDMANN, K. A. and MARKS, M. D. (1994). The glabra 2 gene encodes a homeo domain protein required for normal trichome development in Arabidobsis. Genes Dev. 8, 1388-1399.

SAEDLER, R., MATHUR, N., SRINIVAS, B. P., KERNEBECK, B., HULSKAMP, M. and MATHUR, J. (2004). Actin control over microtubules suggested by DISTORTED2 encoding the Arabidopsis ARPC2 subunit homolog. Plant and Cell Physiol. 45, 813-822.

SCHELLMANN, S., SCHNITTGER, A., KIRIK, V., WADA, T., OKADA, K., BEERMANN, A., THUMFAHRT, J., JURGENS, G. and HULSKAMP, M. (2002). TRIPTYCHON and CAPRICE mediate lateral inhibition during trichome and root hair patterning in Arabidopsis. EMBO J.21, 5036-5046.

SCHNITTGER, A., FOLKERS, U., SCHWAB, B., JÜRGENS, G. and HULSKAMP, M. (1999). Generation of a Spacing Pattern: The Role of TRIPTYCHON in Trichome Patterning in Arabidopsis. Plant Cell 11, 1105-1116.

SCHNITTGER, A., JURGENS, G. and HULSKAMP, M. (1998). Tissue layer and organ specificity of trichome formation are regulated by GLABRA1 and TRIPTYCHON in Arabidopsis. Development 125, 2283-9.

SCHNITTGER, A., SCHÖBINGER, U., BOUYER, D., WEINL, C., STIERHOF, Y.-D. and HULSKAMP, M. (2002a). Ectopic D-type cyclin expression induced not only DNA replication but also cell division in Arabidopsis trichomes. Proc. Natt. Acad. Sci. USA 99, 6410-5415.

SCHNITTGER, A., SCHOBINGER, U., STIERHOF, Y.D. and HULSKAMP, M. (2002b). Ectopic B-type cyclin expression induces mitotic cycles in endoreduplicating Arabidopsis trichomes. Curr. Biol. 12, 415-20.

SCHNITTGER, A., WEINL, C., BOUYER, D., SCHOBINGER, U. and HULSKAMP, M. (2003). Misexpression of the cyclin-dependent kinase inhibitor ICK1/KRP1 in single-celled Arabidopsis trichomes reduces endoreduplication and cell size and induces cell death. Plant Cell 15, 303-15.

SCHWAB, B., MATHUR, J., SAEDLER,-R., SCHWARZ, H., FREY, B., SCHEIDEGGER, C. and HULSKAMP, M. (2003). Regulation of cell expansion by the DISTORTED genes in Arabidopsis thaliana: actin controls the spatial organization of microtubules. Mol. Genet. Genomics 269, 350-360.

SMITH, L. G. (2003). Cytoskeletal control of plant cell shape: getting the fine points. Curr. Opin. Plant Biol. 6, 63-73.

SUGIMOTO-SHIRASU, K., STACEY, N. J., CORSAR, J., ROBERTS, K. and MCCANN, M. C. (2002). DNA Topoisomerase Vl is essential for endoreduplication in Arabidopsis. Curr. Biol. 12, 1782-1786.

SVITKINA, T. M. and BORISY, G. G. (1999). ARP2/3 complex and actin depolymerizing factor/cofilin in dendritic organization and treadmilling of actin filament array in lamellipodia. J. Cell Biol. 145, 1009-1026.

SZYMANSKI, D. B., JILK, R. A., POLLOCK, S. M. and MARKS, M. D. (1998). Control of GL2 expression in Arabidopsis leaves and trichomes. Development 125, 11611171.

SZYMANSKI, D. B. and MARKS, M. D. (1998). GLABROUS1 overexpression and TRIPTYCHON alter the cell cycle and trichome cell fate in Arabidopsis. Plant Cell 10, 2047-2062.

SZYMANSKI, D. B., MARKS, M. D. and WICK, S. M. (1999). Organized F-actin is essential for normal trichome morphogenesis in Arabidopsis. Plant Cel/ 11, 23312348.

TELFER, A., BOLLMAN, K. M. and POETHIG, R. S. (1997). Phase change and the regulation of trichome distribution in Arabidopsis thaliana. Development 124, 645654.

TRAAS, J., BELLINI, C., NACRY, P., KRONENBERGER, J., BOUCHEZ, D. and CABOCHE, M. (1995). Normal differentiation patterns in plants lacking microtubular preprophase bands. Nature 375, 676-677.

WADA, T., KURATA, T., TOMINAGA, R., KOSHINO-KIMURA, Y., TACHIBANA, T., GOTO, K., MARKS, M. D., SHIMURA, Y. and OKADA, K. (2002). Role of a positive regulator of root hair development, CAPRICE, in Arabidopsis root epidermal cell differentiation. Development 129, 5409-19.

WALKER, A. R., DAVISON, P. A., BOLOGNESI-WINFIELD, A. C., JAMES, C. M. SRINIVASAN, N., BLUNDELL, T. L., ESCH, J. J., MARKS, M. D. and GRAY, J. C. (1999). The TRANSPARENT TESTA GLABRA1 Locus, Which Regulates Trichome Differentiation and Anthocyanin Biosynthesis in Arabidopsis, Encodes a WD40 Repeat Protein. Plant Cell 11, 1337-1349.

WALKER, J. D., OPPENHEIMER, D. G., CONCIENNE, J. and LARKIN, J. C. (2000) SIAMESE, a gene controlling the endoreduplication cell cycle in Arabidopsis thaliana trichomes. Development 127, 3931-3940.

YANG, Z. (2002). Small GTPases: Versatile signaling switches in plants. Plant Cell Supplement, S375-S388.

ZHANG, F., GONZALEZ, A., ZHAO, M., PAYNE, C. T. and LLOYD, A. (2003). A network of redundant bHLH proteins functions in all TTG1-dependent pathways of Arabidopsis. Development 130, 4859-69.

ZIMMERMANN, I., SAEDLER, R., MUTONDO, M. and HULSKAMP, M. (2004). The Arabidopsis GNARLED gene encodes the NAP125 homolog and controls several actin-based cell shape changes. Mol Genet Genomics. 